Психология. Журнал Высшей школы экономики.

2020. T. 17. № 1. C. 43-59. DOI: 10.17323/1813-8918-2020-1-43-59

\title{
СЕБЯ НЕ УБИВАЕТ ТОТ, КТО НЕ ХОЧЕТ УБИТЬ ДРУГОГО
}

\section{М.М. РЕШЕТНИКОВ}

"Восточно-Европейский институт психоанализа, Россия, 197198, Санкт-Петербург, Большой nросп., П.С., 18-A

\section{Резюме}

В статье рассматриваются традиционные и новые формы суицидального поведения, которые анализируются в рамках представлений о влечении к смерти. Особое внимание уделяется таким феноменологиям, как «группы смерти» и «суицидальный терроризм». Если ранее суицид практически всегда описывался как единичный случай отдельного человека, осуществляемый самостоятельно и добровольно, то в последние десятилетия появились сотни случаев, когда суициденты не только убивали себя, но и одновременно демонстративно уничтожали десятки и даже сотни ни в чем не повинных людей. Обобщаются результаты психоаналитических исследований случаев суицидального поведения, в частности: «Исследования истерии» (случай Анны О.), «Человек-волк», «Человек-крыса», «Случай Доры», «Психоаналитические заметки об одном случае паранойи», «О психогенезе одного случая женской гомосексуальности», «Печаль и меланхолия». Затрагиваются проблемы утраты смыслов и извращения идеологических установок в современном обществе в ряду ведущих причин роста агрессивного и суицидального поведения.

Ключевые слова: суицид, группы смерти, суицидальный терроризм, мотивы суицидального поведения, утрата смыслов.

Есть много способов расстаться с жизнью. Лучший из них - продолжать жить.

\section{Удручающая статистика}

Начнем с определения. Самоубийство, суицид (от лат. sui caedere - убивать себя) - преднамеренное лишение себя жизни, как правило, осуществляемое самостоятельно и добровольно. По официальным данным, в современном мире ежегодно заканчивают жизнь самоубийством около миллиона человек (Положий, 2016). На самом деле эта цифра занижена как минимум вдвое, так как ряд вариантов добровольного ухода из жизни далеко не всегда квалифицируется как суицид.

Особенно удручающими являются сообщения российских социологов о том, что попытка совершения суицида имеется в анамнезе каждого двенадцатого подростка, при этом количество завершенных суицидов среди юношей в три раза больше, чем у девушек, т.е. в каждом классе средней школы или в студенческой 
группе вуза имеется как минимум два потенциальных суицидента. Существует и более печальная статистика, однако в целом следует признать, что статистические данные психологов, социологов и психиатров об этой феноменологии существенно различаются и точными данными не обладает никто (Ефремов, 2018; Попов, Пичиков, 2017; Моховиков, 2013). Одновременно с этим феноменология суицидального поведения в XXI в. претерпела определенные трансформации и начала качественно меняться.

\section{«Группы смерти»}

В 2010-х гг. особое внимание специалистов вызвало появление хэштегов «групп смерти», популяризирующих в социальных сетях суицид и способы ухода из жизни. В ноябре 2016 г. по обвинению в подстрекательстве и доведении подростков до самоубийства был арестован один из самых известных организаторов таких групп - Филипп Будейкин (группа «Синий кит»). В интервью питерской газете этот недоучка-психолог на вопрос «Действительно ли он подталкивал подростков к смерти?» ответил: «Да. Я действительно это делал. Не волнуйся, ты все поймешь. Все поймут. Они умирали счастливыми. Я дарил им то, чего у них не было в реальной жизни: тепло, понимание, связь». В целом последняя фраза, вне сомнения, страдающего психическим расстройством юноши достаточно адекватно демонстрирует дефицит определенных чувств и одни из ведущих мотивов суицида у подростков. В первую очередь следовало бы выделить несформированное чувство привязанности, из которого затем произрастают взаимопонимание и теплота межличностных отношений. Все эти чувства формируются только в нормально функционирующей семье. А кризис современной семьи хорошо известен.

Клубы самоубийц существовали во времена Древнего Египта, а в XIX в. получили некоторое распространение в Германии, Австрии и США, объединяя людей эксцентричных и далеко не всегда здоровых психически. Кроме своеобразной «моды» на эксцентричность, в данном случае нужно учитывать и феномен психического заражения определенными психическими установками, как в случае, который приводит В.М. Бехтерев (2017), когда в одном из домов инвалидов во Франции в один день повесились 15 человек. История психиатрии предоставляет множество подтверждений тому, что маниакальные личности склонны настойчиво и предельно искренне проповедовать свои идеи, иногда им это удается (достаточно вспомнить крестовые походы детей к Гробу Господню).

Однако до 1980-х гг. встречи с маньяками были редки, случайны и выпадали всегда на долю наиболее внушаемых, незрелых личностей, детей и подростков на улице, преимущественно в районах с «дурной репутацией». Интернет не только ввел этих маньяков в наши дома (от ветхих жилищ до фешенебельных усадеб), но и сделал их полноправными членами наших семей, иногда даже более авторитетными и влиятельными, чем неспособные уделить ребенку достаточно времени и внимания родители. Как убедительно было обосновано в детской психологии, ребенок любит не игру, а того, кто с 
ним играет. А современные дети с дошкольного возраста играют не с родителями, не в машинки и куклы, а с гаджетами. В итоге компьютер становится самым любимым объектом, удовлетворяющим потребность ребенка в общении, и тем почти живым существом, которому бесконечно доверяют, к которому привязываются и которому хотят понравиться, так же как предшествующие поколения старались демонстрировать послушание, чтобы заслужить любовь родителей.

С февраля 2017 г. в России началась «зачистка» хэштегов «групп смерти» в Интернете - удаление постов и комментариев, «заморозка» личных страниц и т.д. Однако статистические данные показали, что предпринимаемые ограничительные и репрессивные меры не привели к ожидаемым результатам. Количество игроков «групп смерти» не только не стабилизировалось, а даже возросло, и к началу 2017 г. их насчитывалось уже более 41 000. При этом бо́льшая часть таких «проектов» и «игроков» переместилась из ВКонтакте в Инстаграм. Здесь следует упомянуть еще одну характерную особенность: такие преступные действия в Интернете по подстрекательству или по доведению до самоубийства чрезвычайно трудно доказуемы. Так, в случае уже упомянутого выше Ф. Будейкина из 15 эпизодов в суде были доказаны только два.

Создатели таких групп действуют достаточно грамотно с ориентацией на психологию подростков, предрасположенных к интроверсии и испытывающих чувство одиночества. В обращениях к таким респондентам достаточно часто используются фразы типа: «Это группа для тех, кого никто не понимает, у кого есть свой голос и кто хочет быть услышанным...» Здесь нужно отметить еще одну особенность. В доинтернетную эпоху побуждение к суициду носило личностно окрашенный и, как правило, корыстный характер, направленный на кого-то из ближайшего окружения (в борьбе за наследство, любовный, социальный или материальный статус и т.д.). В данном случае речь идет о подстрекательстве к самоубийству совершенно незнакомых юношей и девушек, единственным мотивом которого является удовлетворение своего патологического стремления к власти над поведением и жизнью других людей, осуществляемого, по сути, анонимно.

При незначительной вариативности отдельных показателей, по усредненным данным 25\% причин юношеских суицидов связаны с проблемами в личной жизни, $18 \%$ - с отношениями с родителями и другими членами семьи, 15\% поставляют проблемы со сверстниками, 11 \% связаны с неудачами и разочарованиями, $9 \%$ - с чувством одиночества. В совокупности эти пять типов проблем составляют основу 78\% юношеских суицидов (Ефремов, 2018; Попов, Пичиков, 2017; Положий, 2016; Моховиков, 2013). Гораздо более широкий перечень проблем приводится В.М. Бехтеревым в его работе «О причинах самоубийства и возможной борьбе с ним» (2017), которую следовало бы внимательно изучить всем, кто занимается этой проблемой. 


\section{Психоанализ мотивов суицидального поведения}

Любой случай суицида, как правило, подвергается исследованию, преимущественно правоохранительными органами, но обычно лишь на уровне возможных предпосылок и сознательных мотивов (путем опроса родных, друзей, знакомых, изучения переписки и т.д.). Но фактически все это делается «для протокола», т.е. весьма поверхностно, и вряд ли стоит особенно доверять полицейским дознаниям или сведениям, полученным от родственников.

В этом разделе мы обратимся к подробным исследованиям суицидального поведения в работах 3. Фрейда и его ближайших последователей. Напомним, что в 1920-е гг. в психоанализе впервые было обозначено понятие «влечение к смерти» (Фрейд, 2006в), наличие которого у каждого человека в настоящее время общепризнанно. Гораздо труднее принимается идея о том, что в психике каждого из нас в той или иной степени присутствуют суицидальные тенденции, которые традиционно рассматриваются в контексте уже обозначенного влечения к смерти, инстинкта агрессии и самодеструкции (Адлер, 2011; Фрейд, 2006а).

Это удивительно, но в большинстве случаев феномен суицида даже в психоаналитических исследованиях затрагивается как некая табуированная тема, которая, как правило, описывается весьма кратко и упоминается как бы «на полях». После прочтения той или иной работы З. Фрейда эта тема оказывается почти забытой, вытесненной или утонувшей в потоке другой информации.

Практически все знают хрестоматийный случай Анны О., который обычно определяется как типичный вариант истерии (Решетников, 2016; Фрейд, 2005) и как первое применение психоаналитического метода. Но мало кто помнит, с чего все начиналось. Анна О. (Берта Паппенхейм) вовсе не была законченной истеричкой. Но она пережила несколько психических травм. Когда ей было 8 лет, от туберкулеза умерла ее старшая сестра Генриетта. В этот же период семья значительно обеднела. В итоге Берта была вынуждена бросить школу и помогать по хозяйству матери, завидуя младшему брату, который продолжал учиться в гимназии. В 1880 г. ее отец тяжело заболел плевритом, однажды во время бессонной ночи у постели больного у Анны начались галлюцинации и приступы страха. В последующем к этим симптомам присоединились транзиторные нарушения зрения и речи, невозможность говорить на родном языке, парезы лицевых мышц и правой руки, отказ от еды, перепады настроения и т.д. Состояние девушки резко ухудшилось после смерти отца (5 апреля 1881 г.). Анна в течение нескольких суток отказывалась от пищи, била окна в своем доме и пыталась осколками стекла вскрыть себе вены. Врачи, что было естественным для того периода времени, рекомендовали ей свежий воздух, смену обстановки, хлорал и другие успокаивающие средства. И лишь в процессе терапии методом катарсиса у Й. Брейера (который был другом семьи Паппенхейм) наступило значительное улучшение.

Согласно заключению Й. Брейера, терапия достигла своей цели 7 июня 1882 г., после того как Анна реконструировала (в катарсисе) первую ночь с галлюцинациями у постели тяжело больного отца. «С тех пор она совершенно 
здорова», - констатировал Й. Брейер в истории болезни Анны. Но, как это нередко случается у истероидных личностей, на смену одному невротическому синдрому пришел другой, в данном случае - синдром мнимой беременности. Крайне огорчившись таким развитием событий и опасаясь всяческих слухов и домыслов коллег, Брейер тут же прекратил все контакты с пациенткой и уехал с женой в Италию. Но З. Фрейд по-своему интерпретировал этот случай, объяснив и наступление улучшения, и появление нового синдрома особым отношением Анны к отцу, а затем переносом этого отношения на своего терапевта. Так в психоанализе впервые появилось понятие «переноса» (1895), а также был вскрыт один из бессознательных мотивов суицида, связанный с детско-родительскими отношениями. Впоследствии Берта Поппенхейм приобрела известность как общественный деятель и публицист, стала лидером движения за права женщин. Она прожила долгую жизнь и умерла в возрасте 77 лет.

В 1901 г. в своей работе «Психопатология обыденной жизни» (Фрейд, 2018) 3. Фрейд вспоминает о случае 1898 г., когда один из его пациентов покончил с собой из-за неизлечимой болезни половых органов. Этот случай лишь упоминается, и мы не имеем никаких сведений ни об этом пациенте, ни о его анализе. Тем не менее это позволяет сформулировать еще одну гипотезу - о связи суицидального поведения с сексуальной сферой и любовными отношениями. Эта тема обсуждалась 3. Фрейдом не только в связи с его пациентами, но затрагивалась и самим создателем психоанализа. В 1885 г. в письме к своей будущей жене 3. Фрейд писал, что готов покончить с собой, если они расстанутся (Фрейд, 2011). В последующем Фрейд не раз возвращался к этой теме, проводя параллели и вскрывая связи между влюбленностью (как вариантом сумасшествия) и самоубийством.

В работе «Психическая травма» (Решетников, 2018) мне уже приходилось подробно анализировать психодинамику кризиса любовных отношений. Когда человек кого-то любит, он частично инвестирует свое Я в любимый объект (объект своей любви), но по большей части (в силу естественного нарциссизма) интроецирует любимый объект в собственное Я (Эго) вплоть до метафорического желания поглощения и присвоения этого объекта (своим Я). В случаях реальной влюбленности Эго переполнено объектом. Таким образом, происходит расширение и обогащение своего Я (за счет инкорпорированного объекта). Утрата такого дорогого объекта независимо от того, произошла ли она реально или предчувствуется только возможность такой утраты, провоцирует мощнейший конфликт между собственным Супер-Эго и связанным с инкорпорированным, но утраченным любимым объектом и потому ослабленным Эго. При этом Супер-Эго трансформируется в жестокую карающую инстанцию психики, которая терзает, мучает и обвиняет собственное Эго в этой утрате и, лишая его защит, побуждает к самодеструктивному поведению (начиная с обычая ударять кулаком по столу, биться головой о стену или наносить себе раны и увечья - вплоть до суицида).

В изложении случая одного из самых известных пациентов Фрейда Сергея Панкеева - «Человека-волка» (Фрейд, 2007) - «за кадром» присутствует 
идея семейной предрасположенности к суицидам, которая некоторыми авторами интерпретировалась как генетически заданная. Но, думаю, этот случай следовало бы отнести к сугубо психологическим (патологическим) идентификациям и специфическому семейному фону. Сергей Панкеев, как известно, страдал депрессией и имел ряд других симптомов, которые обострились после самоубийства его любимой сестры. Обнаружив у единственного сына суицидальные мысли, отец Панкеева (который и сам был склонен к депрессиям) консультировал Сергея у крупнейших ученых того времени - В.М. Бехтерева и Э. Крепелина, но Панкеев проникся доверием только к 3. Фрейду. Этот случай был многократно описан, проанализирован и переанализирован, в том числе автором этой статьи в работе «Два случая злоупотребления одним пациентом» (Решетников, 2017). Как известно, Панкеев начал анализ у Фрейда в январе 1910 г. и завершил его в 1914 г., при этом завершил успешно, о чем Фрейд поведал научному сообществу в одной из своих самых известных работ («Из истории одного инфантильного невроза», 1918). Нужно отметить, что личность Фрейда настолько поразила и впечатлила Панкеева, что он сразу сообщил отцу о своем окончательном решении проходить терапию именно у него, и это было одним из существенных факторов будущей успешной терапии.

В процессе анализа, в первую очередь, вскрылись детские страхи Панкеева, в том числе - страх кастрации. Когда ему было три года, его старшая сестра, вероятно, из обычного любопытства изучала его пенис или играла с ним. Однако в любом случае это должно интерпретироваться как соблазняющее поведение и одновременно как угроза для ребенка, не достигшего сексуальной зрелости. Позднее подросший Панкеев проявлял соблазняющее поведение в отношении няни, «играя» своим пенисом у нее на глазах, и получил еще одну - более реальную угрозу кастрации. Няня строго сказала, что если он будет так делать, на этом месте появится рана. Как предполагал 3. Фрейд, Сергеев Панкеев пережил также травму «первичной сцены», в результате чего он регрессировал к анальной стадии развития, а его (проявлявшиеся в раннем детстве) садистические наклонности трансформировались в мазохизм, идеи самодеструкции и бесцельности бытия. Но уже через несколько первых месяцев психоанализа Панкеев отметил, что перед ним открылся совершенно новый мир, многое из того, что он не мог понять в своей жизни, стало проясняться. Благодаря моей практике и супервизиям, мне известно множество случаев, когда аналогичные заключения делали люди, которые приходили в анализ с чувством полной безысходности и утраты надежд на счастье. Страдавший от депрессии и проявлявший в юности склонность к суицидальному поведению Сергей Панкеев прожил большую жизнь. До 1950 г. он работал агентом в венской страховой компании, затем вышел на пенсию и умер в возрасте 92 лет (7 мая 1979 г.), пережив самоубийство своей любимой жены Терезы Келлер (в 1938), бывшей медсестры мюнхенского санатория, где Панкеев лечился.

Затем был случай Доры (1905) - молодой девушки, фрустрированной изменой отца с женой господина К., в которого она была тайно влюблена и 
который в отместку за измены жены (и одновременно - отцу Доры) пытался ее соблазнить, осыпая ее поцелуями, несмотря на сопротивление девушки. Охваченная аффективными чувствами, Дора написала родителям письмо, где навсегда прощалась с ними (Фрейд, 2012). Напомню, что это письмо было «случайно» оставлено на самом видном месте в гостиничном номере родителей. Письмо было, естественно, обнаружено, и родители девушки обратились за помощью к З. Фрейду.

В своей практике мне приходилось не раз встречаться с подобными случаями - «нечаянного» раскрытия суицидальных мыслей родителям или супругам через друзей и подруг или других родственников. В процессе анализа мотивов таких поступков и даже предпринятых демонстративных суицидов (обычно с запланировано благополучным исходом) самым частым объяснительным мотивом было: «Вот тогда они наконец поймут...!» Объяснения того, что должны были бы понять самые близкие люди, были самыми различными: от высокодуховных до самых примитивных. В одних случаях это были те или иные неразделяемые семейным окружением идеи, включая религиозные, проблемы нетрадиционной сексуальной ориентации и т.д., а в других, например, отказ родителей приобрести модный смартфон для 14-летней дочери.

Однако самое главное в подобных случаях состоит в том, что идея самоубийства может быть своеобразным посланием, и в процессе терапии очень важно установить не только мотив, но и то, кому было адресовано это послание и как оно трансформируется в процессе переноса. Обычно эти «адресаты» находятся в числе самых дорогих, самых любимых и любящих, а иногда ими становятся и сами терапевты. Дополнительно нужно отметить, что в отличие от определения ВОЗ (2011), утверждающего, что «самоубийство есть результат сознательных действий со стороны определенного человека», молодые суициденты в большинстве случаев действуют абсолютно спонтанно, побуждаемые чувствами, аффектами и бессознательными мотивами. Случаи полного осознания своих действий характерны почти исключительно для так называемых альтруистических самоубийств - неизлечимо больных пожилых людей, основным мотивом которых является желание избавления от излишних страданий как себя самого, так и своих близких. Иногда такие «альтруистические суициды» были следствием бегства от позора, как у ВИЧ-инфицированных в период бездумной стигматизации таких пациентов.

В 1909 г. выходит описание случая, получившего наименование «Человеккрыса» (Фрейд, 2007), где обосновывается еще один мотив, побуждающий к самоубийству, а именно - мотив соперничества и амбивалентности. 29-летний юрист Эрнст Ланзер страдал обсессивным неврозом - был подвержен навязчивым мыслям и выполнению неких ритуалов, настолько парализовавшим его жизненные силы и активность, что он полностью утратил трудоспособность. Симптомы впервые появились, когда, находясь на службе в армии, пациент услышал рассказ о жестокой восточной пытке: к ягодицам приговоренного привязывали горшок с крысами, которые разгрызали задний проход несчастного. Эта «картина» в сознании Ланзера начала проецироваться на его отца и его даму сердца, к которым он испытывал амбивалентные чувства. 
Позднее этой случай был интерпретирован и как вариант анальной эротики. Терапия, которую провел 3. Фрейд, была успешной. Психическое состояние пациента полностью восстановилось, и он возобновил свою деятельность и контакты с другими людьми, которых ранее избегал. В августе 1914 г. Ланзер был призван в армию, попал в плен и погиб.

В начале XX в. исследование мотива соперничества было наиболее убедительно обосновано при исследовании суицидов студентов венских университетов, где безусловными лидерами оказались молодые люди творческих профессий - музыканты и художники. Этому было дано вполне адекватное объяснение. После периода признания уникальности их способностей в детском и юношеском возрасте со стороны родителей и сверстников в тех или иных провинциальных центрах, поступив в столичную художественную школу или консерваторию, эти молодые люди «вдруг» оказывались в среде куда более способных и талантливых, и для некоторых это соперничество становилось непреодолимым. Повторим: здесь мы встречаем еще один мотив суицида вариант преодоления нарциссической травмы и соперничества.

Нужно упомянуть также случай паранойи судьи Шребера (1911), который неоднократно просил лечащих врачей дать ему цианистый калий и пытался утопиться (Фрейд, 2006б). Уникальность этой работы, названной «Психоаналитические заметки об одном случае паранойи...», состоит в том, что Фрейд никогда не встречался с доктором юриспруденции ДаниэлемПаулем Шребером, а провел анализ «Мемуаров нервнобольного», опубликованных в 1903 г. самим Шребером. Этот случай, безусловно, уникален. Впервые психическое расстройство (ипохондрическая депрессия) проявилось у Шребера в возрасте 42 лет, когда он проиграл выборы в депутаты рейхстага. Тогда он провел несколько месяцев в клинике профессора Флексига и был выписан после выздоровления. Однако в 53 года после назначения его на должность президента коллегии Апелляционного суда одной из провинций у него развился острый галлюцинаторный бред, который потребовал повторной госпитализации в ту же клинику, где Шребер провел восемь лет. Он покинул клинику только после своего выступления перед трибуналом суда Дрездена, где сам выступил в свою защиту и доказал, что он не представляет опасности для социума. Именно для этого суда он написал «Мемуары...», чтобы обосновать свое право покинуть клинику и выйти на свободу. Шребер достиг желаемого, но через пять лет у него произошел новый рецидив психоза, и он снова поступил в ту же клинику, где провел еще четыре года, вплоть до своей смерти (1911).

«Ядро» паранойи Шребера было связано с идеей его особой миссии по спасению мира, но для этого ему вначале нужно было превратиться в женщину. При интерпретации этого случая Фрейд приходит к выводу, что причиной психического расстройства был «наплыв» гомосексуального либидо, объектом которого (на фоне предшествующей депрессии) стал лечащий доктор Шребера - профессор Флехсиг. Таким образом, мы можем констатировать еще один фактор побуждения к суицидальному поведению - внутриличностные конфликты на основе отклонений в сексуальной идентификации. Фрейд 
еще раз возвращается к этой идее в работе «О психогенезе одного случая женской гомосексуальности» (1920), где причиной побуждения к суицидальным мыслям и попытке броситься под поезд стала ревность молодой девушки к матери и ее позднему ребенку (Фрейд, 2019). В результате этих переживаний дочь отвернулась от матери и обратила свою любовь на другую женщину, гораздо старше себя.

Обратимся также к одной из самых известных работ 3. Фрейда «Печаль и меланхолия» (1917), где в качестве ведущей симптоматики выступала вовсе не депрессия (со временем обретшая некое упрощенно-схематическое описание), а непреодолимое чувство вины и бесконечные самообвинения.

Периодические расстройства настроения, когда уместен вопрос: «Ты чемто расстроен?» - знакомы каждому. У этих расстройств есть та или иная, обычно рациональная, поддающаяся анализу и объяснению связь с той или иной ситуацией или психической травмой. В периоды расстройства человек чувствует или даже демонстрирует снижение общей энергичности, некоторую заторможенность, погруженность в себя, определенное застревание на какойто психотравмирующей теме с явным ограничением интереса ко всем другим, склонность к уединению или, наоборот, обсуждению этой темы с кем-то близким, а иногда - и вовсе незнакомым. Конечно, при этом страдает и работоспособность, и самооценка, но личность сохраняет способность действовать и взаимодействовать с другими, понимать себя и других, включая причины своего плохого настроения. Фрейд обозначает это как обычную скорбь. В этих случаях, как правило, никому не приходит в голову обращаться к психотерапевту или психологу. И в типичной бытовой ситуации через некоторое время люди забывают и о своем расстройстве, и о ситуации, которая стала его причиной. Такое поведение не воспринимается как патологическое, так как у него всегда есть причина и конкретное объяснение.

В отличие от этого меланхолия (этот термин у Фрейда эквивалентен тяжелой депрессии) является качественно иным состоянием. Фрейд отмечает, прежде всего, утрату интереса ко всему внешнему миру, всеобъемлющую заторможенность, неспособность к какой-либо деятельности в сочетании с понижением чувства собственного достоинства, которое выражается в бесконечном потоке упреков и оскорбительных высказываний по поводу собственной личности. В отдельных случаях это перерастает в бредоподобное чувство вины и ожидание наказания за свои реальные или фантазийные прегрешения, которым, по ощущениям пациента, нет прощения. Но самое главное отличие от обычной скорби состоит в том, что пациент сознательно (самостоятельно) не может найти причину своего страдания.

Фрейд называет это величественным обеднением Я и отмечает, что если при скорби мир становится бедным и пустым, то при меланхолии таким становится само Я. Пациент подает себя как исключительно мерзкую, ни на что не способную, даже отвратительную личность и нередко удивляется тому, что терапевт связался и возится с таким недостойным, никчемным человеком. Эта специфика меланхолии хорошо известна специалистам, а связь суицидов с депрессивными состояниями является общепризнанной, в целом все случаи 
тяжелой депрессии можно было бы отнести к предсуицидальным состояниям (Решетников, 2017, 2003; Моховиков, 2013). Нередко в основе такого состояния лежат некие события в предшествующей (иногда самых ранних периодов) жизни пациентов, которые настолько мерзки, отвратительны и, по определению Фрейда, «издают зловоние», что и помнить о них невозможно, и забыть нельзя. Достучаться до таких воспоминаний чрезвычайно сложно. Образно говоря, нельзя вспомнить то, что не было забыто. А основной целью терапии в этих случаях становится восстановление (в безопасной обстановке) этих устрашающих, реальных, частично или даже полностью фантазийнотрансформированных провоспоминаний, лишение их нагара неестественности и мучительного страха за вину, которая чаще всего не принадлежит тому, кто предъявляет такие симптомы.

Приведу в качестве поясняющего примера краткое описание одного из подобных случаев, подробно изложенного в моей книге «Частные визиты». Пациентка в возрасте около 30 лет (иногородняя, с высшим образованием) направлена ко мне ее матерью в связи с тяжелой депрессией, полной утратой работоспособности и серией суицидных попыток. На протяжении нескольких десятков сессий пациентка обещает рассказать мне о ее главном симптоме, но не называет его, мотивируя тем, что она еще не готова этим поделиться. В конце концов симптом был назван: в минуты волнения (даже обычного, а особенно сексуального) у пациентки случается недержание газов. Понадобилось еще много месяцев бережного погружения в ее ранние воспоминания, прежде чем пациентка вспомнила, что, когда она была маленькой девочкой, после скандалов и разладов с отцом ее мать приходила в ее постель и совершала над ней сексуальные действия развратного характера. До терапии пациентка не помнила об этом и даже в терапии не сразу поняла, что появление ее «симптома» носило защитный характер, и его целью было сделать ее неприятной как сексуальный объект. Я не могу назвать этот случай успешным, так как после выяснения отношений пациентки с матерью последняя тут же перестала оплачивать сессии и забрала дочь домой.

Обратим внимание на то, что при всех различиях клинических проявлений практически у всех пациентов были идеи суицида. Это позволяет сделать вывод, что фактически не бывает психических расстройств без суицидальной предрасположенности, и наоборот. Позднее, благодаря 3. Фрейду и его последователям, в психоанализе было практически общепризнанно, что мысли о самоубийстве являются не чем иным, как обращенным на себя побуждением к убийству кого-то другого - предавшего, соперничающего, непонимающего, бесконечно любимого и одновременно столь же ненавистного (Адлер, 2011; Фрейд, 2006а; Штекель, 2011).

При этом местом «локализации» таких мыслей являются бессознательная часть Эго (личности) и Супер-Эго. Бесполезно искать эти мысли в гипотетической структуре Ид, которому неведома смерть. Для того чтобы жить и чувствовать себя счастливым, Эго должно чувствовать себя любимым со стороны своего Супер-Эго (это и составляет одну из целей и задач терапии). Тем не менее мы должны признать, что у каждого в жизни случаются ситуации, когда 
тяготы бытия кажутся непереносимыми и наша терпимость по отношению к ним и к самим себе истощается, как следствие жизнь утрачивает смысл, становится пресной или даже обесценивается. В таких случаях, конечно, нужен Другой, который хорошо подготовлен к тому, чтобы временно подставить свое Эго в качестве «костыля» захромавшему.

\section{О суицидальных террористах}

Обратимся к специфике некоторых суицидных актов современной эпохи. Ранее суицид практически всегда описывался как единичный случай отдельного человека и трагедия его ближайшего окружения. Но сейчас уже зарегистрированы сотни качественно иных случаев. Самым потрясающим из них стала трагедия рейса A320-211 компании «Germanwing» (24 марта 2015 г.), когда страдающий психическим расстройством пилот Андреас Лубиц, совершая суицид, умышлено направил авиалайнер в склон горы, «захватив с собой» 144 пассажира и 6 членов экипажа. Это, безусловно, качественно иное проявление человеческой агрессивности и ее частного случая - человеконенавистнической суицидальности, которая пока недостаточно исследована. В ряде своих работ и в переписке с Альбертом Эйнштейном Зигмунд Фрейд не раз проводил аналогию между самоубийством и войной (Фрейд, 1992). Давайте представим, что будет, если какой-то суицидент, принадлежащий, как и пилот Лубиц, к субъектам высоких технологий, например, оператор атомной станции, оператор пуска баллистических ракет или даже оператор обычной плотины, захочет «прихватить» с собой в мир иной несколько тысяч или несколько миллионов людей.

Такие идеи активно популяризируются в пособиях для террористов-смертников, где, в частности, указывается: «Чем больше жертв, тем скорее они поймут». Эти случаи также можно было бы интерпретировать как послание, но, думаю, это было бы неверно. Более адекватным мне представляется объяснение на основе извращенной жажды признания и хотя бы посмертной «славы» и известности своей патологически высокоценимой личности, не способной достичь общественного признания другими путями. Кто бы стал читать 1500-страничный трактат А. Брейвика, если бы этот 32-летний патологический нарцисс не расстрелял 77 своих соотечественников? А после этого ужасающего по своей жестокости и циничности преступления «трактат» был переведен на все основные языки современного мира. Кто бы, кроме нескольких ближайших знакомых, заметил самоубийство 28-летнего второго пилота, если бы он не обрек на смерть еще 160 ни в чем не повинных людей?

\section{Об утрате смыслов}

Одно из дополнительных объяснений подобного поведения дал в 2011 г. Джеймс Фокс, профессор Северо-Восточного университета в Бостоне (США), который констатировал: «В американском обществе существует определенное число людей, которые озлоблены на окружающий мир, полностью в 
нем разочарованы, считают свою жизнь разрушенной и не хотят больше жить. Эти люди испытывают недостаток эмоциональной поддержки со стороны семьи и друзей и решают жестоко отомстить тем, кто, по их мнению, несет ответственность за их неудачи и не дает им шанса справиться с жизненными проблемами. Выбирая между суицидом и кровавой расправой, они, как правило, выбирают

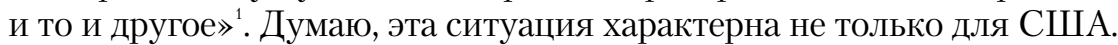

Еще в 1960-е гг. В. Франкл констатировал распространение в самых широких слоях населения утраты смысла жизни (Франкль, 2019). Согласно приведенной им статистике, при этом возрастает уровень депрессивности, наркоманий, алкоголизма и агрессивности, в том числе аутоагрессии. В процессе длительной дискуссии питерских ученых (в начале 2000-х гг.) ее участники пришли к выводу, что смыслы жизни не находятся, а привносятся выдающимися мыслителями, такими как Вольтер, Дидро, Руссо, Локк, Гоббс или даже Маркс. Кроме того, было обосновано, что смыслы появляются только тогда, когда у каждого конкретного человека есть какая-то благая или даже иллюзорная цель, которая выходит далеко за рамки его повседневного существования и объединяет его с другими людьми. Есть ли у нас как у человечества или хотя бы как у граждан конкретной страны такие идеи и цели? Неужели мы все пришли в этот мир только для того, чтобы вдоволь поесть, сделать модную прическу или тату́, заработать на новые джинсы или новый смартфон, новую квартиру, машину или дачу? Есть ли где-то выдающиеся мыслители современности, идеи которых способны объединить нас всех?

\section{Идеологический вакуум?}

Понятие идеологии сейчас стало табуированной темой. И некоторые считают, что сейчас нет никакой идеологии. Это не так (к этому тезису мы еще вернемся). Но вначале о роли идеологии. Во-первых, у любой идеологии есть две главные функции: 1) она должна быть объяснительной системой, направленной на сглаживание противоречий; 2) она должна придавать смыслы повседневному бытию и объединять этими смыслами всех граждан страны. Такая идеология была у советских людей, безусловно, иллюзорная и последовательно дискредитированная в процессе коммунистического строительства, но была! Сейчас нет такой идеологии. Как известно, она была одномоментно отменена в 1991 г. И ничего взамен, кроме краткосрочной иллюзии присоединения к благоухающему (а на поверку оказалось: дурно пахнущему) Западу! Это была мощнейшая общенациональная психическая травма - травма утраты смыслов и веры. И в 1992 г. был зафиксирован пик частоты суицидов в России 46.1 на 100 тыс. населения, который затем постепенно снижался и к 2012 г. составил 22.4. Существует множество исследований, в которых анализируется связь уровня суицидов с экологическими и экономическими факторами, нацио-

\footnotetext{
${ }^{1}$ Интервью проф. Дж. Фокса «Российской газете» от 15 декабря 2012 г. в связи с очередной массовой бойней в начальной школе «Сэнди Хук» (США), когда были расстреляны 28 человек, в том числе 20 детей в возрасте от 5 до 10 лет.
} 
нальными традициями и особенностями (Попов, Пичиков, 2017; Положий, 2016; Моховиков, 2013), чего нельзя сказать о социально-психологических факторах и смыслах бытия, которые давно отсутствуют в программах и платформах практически всех партий.

В настоящее время большинство социологов и даже политиков констатируют, что противоречия в обществе, расслоение по материальному статусу и духовным основам нарастают. В целом нужно признать, что такие процессы характерны не только для России, но и для всего мира, где постепенно все бо́льшую популярность приобретают идеи справедливости и борьбы с несправедливостью (Решетников, 2006). Фактически же эта борьба ведется против новой, никем не провозглашенной, но активно действующей идеологии. Это безудержная конкуренция, борьба всех против всех, сакрализация материального успеха и товарный фетишизм. Великие гуманисты ужаснулись бы от такого итога частного предпринимательства, свободной конкуренции и демократии, все более явно превращающейся в демократизм.

\section{Никем не замеченное событие}

В те же 1960-е произошло еще одно никем не замеченное событие. До середины XX в. все развитие человечества шло по пути гуманизации межличностных и межгосударственных отношений в соответствии с идеями, провозглашенными выдающимися мыслителями, уже упомянутыми выше и другими. При этом никто из этих мыслителей не занимал никаких высоких постов они не были министрами, царями, королями или президентами, но министры, монархи и президенты прислушивались к их идеям, принимали их идеи и реализовали их в своей политике. И вдруг в середине ХХ в. происходит качественный сдвиг: право провозглашать новые идеи от выдающихся мыслителей переходит исключительно к первым лицам государств, которые вовсе не обязаны быть выдающимися мыслителями, и обычно принадлежат к личностям лидерского (агрессивного) типа. Они достигают своих высоких положений в результате непримиримого политического соперничества и борьбы и сохраняют установку на такой тип поведения и на такой тип межличностных и межгосударственных отношений. Куда приведут нас эти лидеры современности?

\section{Литература}

Адлер, А. (2011). Влечение к агрессии в жизни и в неврозе. В кн. О. Ранк (сост.), Отчет о первом частном Психоаналитическом собрании в Зальибурге 27 апреля 1908 года (с. 27-28). Ижевск: ERGO.

Бехтерев, В. М. (2017). О причинах самоубийства и возможной борьбе с ним. В кн. Ю. В. Попов, А. А. Пичиков, Суицидальное поведение у подростков (с. 8-44). СПб.: СпецЛит.

Ефремов, В. С. (2018). Оставшиеся в живых: работа с суицидентом (2-е изд.). СПб.: Издательский центр «Ууманитарная академия».

Моховиков, А. Н. (сост.). (2013). Суицидология: прошлое и настоящее: Проблема самоубийств в трудах философов, сочиологов, психотерапевтов и в художественных текстах. М.: Когито-Центр. 
Положий, Б. С. (2016). Суищиды в России и в Европе. М.: Медицинское информационное агентство. Попов, Ю. В., Пичиков, А. А. (2017). Суицидальное поведение у подростков. СПб.: СпецЛит.

Решетников, М. М. (2003). Психодинамика и психотерапия депрессий. СПб.: ВосточноЕвропейский институт психоанализа.

Решетников, М. М. (2006). Интолерантность и терроризм в Европе. В кн. Идея ненасилия в XXI веке: Сборник научных докладов (с. 226-273). Пермь: ПГУ.

Решетников, М. М. (2016). Историко-культурные предпосылки создания психоанализа. В кн. М. М. Решетников (ред.), Психоанализ: учебник для бакалавриата и магистратуры (с. 17-29). М.: Юрайт.

Решетников, М. М. (2017). Два случая злоупотребления одним пациентом. В кн. М. М. Решетников, Трудности и типичные ошибки начала терапии (2-е изд., с. 225-240). М.: Юрайт.

Решетников, М. М. (2018). Психическая травма: учебное пособие для бакалавриата, специалитета и магистратуры (2-е изд.). М.: Юрайт.

Франкль, В. (2019). Страдания от бессмысленности жизни. Новосибирск: Сибирское университетское изд-во.

Фрейд, 3. (1992). Почему война. Переписка с Альбертом Эйнштейном, сентябрь 1932. В кн. 3. Фрейд, По ту сторону принципа удовольствия (с. 325-337). М.: Прогресс/Литера.

Фрейд, 3. (2005). Фрейлейн Анна О. В кн. 3. Фрейд, Собрание сочинений: m. 1. Исследования истерии (с. 39-70). СПб.: Восточно-Европейский институт психоанализа.

Фрейд, 3. (2006, а). Влечения и их судьба. В кн. 3. Фрейд, Собрание сочинений: m. 3. Психология бессознательного (с. 79-111). М.: ООО «Фирма СТД».

Фрейд, 3. (2006, б). Психоаналитические заметки об одном случае паранойи (dementia paranoides), описанном в автобиографии. В кн. 3. Фрейд, Собрание сочинений: т. 3. Одержимость дъяволом. Паранойя (с. 71-146). СПб.: Восточно-Европейский институт психоанализа.

Фрейд, 3. (2006, в). Я и Оно. В кн. З. Фрейд, Собрание сочинений: ного (с. 291-352). М.: ООО «Фирма СТД».

Фрейд, 3. (2007). Собрание сочинений: m. 4. Навязчивые состояния. Человек-крыса. Человек-волк. СПб.: Восточно-Европейский институт психоанализа.

Фрейд, 3. (2011). Письма к невесте. М.: Азбука-классика.

Фрейд, 3. (2012). Фрагмент анализа одного случая истерии. В кн. З. Фрейд, Собрание сочинений: m. 5. Фобические расстройства. Маленький Ганс. Дора (с. 143-268). СПб.: ВосточноЕвропейский институт психоанализа.

Фрейд, 3. (2018). Собрание сочинений: т. 8. Психопатология обыденной жизни. СПб.: ВосточноЕвропейский институт психоанализа.

Фрейд, 3. (2019). О психогенезе одного случая женской гомосексуальности. В кн. 3. Фрейд, Собрание сочинений: m. 10-11. Динамика переноса. Психоаналитическая клиническая теория (с. 349-378). СПб.: Восточно-Европейский институт психоанализа.

Штекель, В. (2011). Об истерии страха. В кн. О. Ранк (сост.), Отчет о первом частном Психоаналитической собрании в Зальцбурге 27 апреля 1908 года (с. 23). Ижевск: ERGO.

Решетников Михаил Михайлович - ректор, Восточно-Европейский институт психоанализа, заслуженный деятель науки РФ, доктор психологических наук, профессор.

Сфера научных интересов: психология, психотерапия, социальные кризисы, экологические и техногенные катастрофы, массовое поведение.

Контакты: veip@yandex.ru 


\title{
Nobody Kills Himself if He Doesn't Want to Kill the Other
}

\author{
M.M. Reshetnikov
}

${ }^{a}$ East European Psychoanalytic Institute (University), 18-A, Bolshoy pr., P.S., Saint Petersburg, 197198, Russian Federation

\begin{abstract}
In this paper, traditional and novel forms of suicidal behavior are analyzed from the perspective of the death drive. Special attention is paid to such phenomena as "death groups" and "suicide terrorism". Previously, suicide was described as a singular act voluntarily and independently committed by an individual, but in the recent decades, hundreds of episodes have occurred, in which suicidal individuals killed dozens or even hundreds of innocent people together with themselves. Results of psychoanalytic studies of suicidal behavior are analyzed, in particular, "Studies of hysteria" (the case of Anna O.), "The Wolf Man", "The Rat Man", "The case of Dora", "Psychoanalytic notes on a case of paranoia", "On the psychogenesis of a case of female homosexuality", "Mourning and melancholy". Such contemporary societal problems as loss of meaning and perverted ideological attitudes are discussed as an influential cause of increase in aggressive and suicidal behavior.
\end{abstract}

Keywords: suicide, death groups, suicide terrorism, motives of suicidal behavior, loss of meaning.

\section{References}

Adler, A. (2011). Vlechenie k agressii v zhizni i v nevroze [The agressive instinct in life and in neurosis]. In O. Rank (Ed.), Otchet o pervom chastnom Psikhoanaliticheskom sobranii v Zal'tsburge 27 aprelya 1908 goda [A report on the First private Psychoanalytic meeting in Salzburg on April 27, 1908] (pp. 27-28). Izhevsk: ERGO. (in Russian)

Bekhterev, V. M. (2017). O prichinakh samoubiistva i vozmozhnoi bor'be s nim [On the reasons of suicide and a possible fight against it]. In Yu. V. Popov \& A. A. Pichikov, Suitsidal'noe povedenie u podrostkov [Suicidal behavior in adolescents] (pp. 8-44). Saint Petersburg: SpetsLit. (in Russian)

Efremov, V. S. (2018). Ostavshiesya v zhivykh: rabota s suitsidentom [The survivors: work with a suicidal person] (2nd ed.). Saint Petersburg: Gumanitarnaya akademiya. (in Russian)

Frankl, V. (2019). Stradaniya ot bessmyslennosti zhizni [The sufferings from the meaninglessness of life]. Novosibirsk: Sibirskoe universitetskoe izdatel'stvo. (in Russian; transl. of: Frankl, V. (2006). Das Leiden am sinnlosen Leben: Psychotherapie fuer heute [The suffering from the meaningless life: Psychotherapy for today]. Freiburg im Breisgau: Herder. (in Deutsch))

Freud, S. (1992). Pochemu voina. Perepiska s Al'bertom Einshteinom, sentyabr' 1932 [Why war? Correspondence with Albert Einstein, September, 1932]. In S. Freud, Po tu storonu printsipa udovol'stviya [Beyond the pleasure principle] (pp. 325-337). Moscow: Progress/Litera. (in Russian) 
Freud, S. (2005). Freilein Anna O. [Fräulein Anna O.]. In S. Freud, Sobranie sochinenii: t. 1. Issledovaniya isterii [Collection of works: Vol. 1. Studies on hysteria] (pp. 39-70). Saint Petersburg: Vostochno-Evropeiskii institut psikhoanaliza. (in Russian)

Freud, S. (2006, a). Vlecheniya i ikh sud'ba [Instincts and their vicissitudes]. In S. Freud, Sobranie sochinenii: t. 3. Psikhologiya bessoznatel'nogo [Collection of works: Vol. 3. The psychology of unconscious] (s. 79-111). Moscow: Firma STD. (in Russian)

Freud, S. (2006, b). Psikhoanaliticheskie zametki ob odnom sluchae paranoii (dementia paranoides), opisannom v avtobiografii [Psychoanalytic notes on a case of paranoia (dementia paranoides), described in an autobiography]. In S. Freud, Sobranie sochinenii: t. 3. Oderzhimost' d'yavolom. Paranoiya [Collection of works: Vol. 3. Demonic possession. Paranoia] (pp. 71-146). Saint Petersburg: Vostochno-Evropeiskii institut psikhoanaliza. (in Russian)

Freud, S. (2006, c). Ya i Ono [Ego and Id]. In S. Freud, Sobranie sochinenii: t. 3. Psikhologiya bessoznatel'nogo [Collection of works: Vol. 3. The psychology of unconscious] (pp. 291-352). Moscow: Firma STD. (in Russian)

Freud, S. (2007). Sobranie sochinenii: $t$. 4. Navyazchivye sostoyaniya. Chelovek-krysa. Chelovek-volk [Collection of works. Vol. 4. Obsessive states. The Wolf Man. The Rat Man]. Saint Petersburg: Vostochno-Evropeiskii institut psikhoanaliza. (in Russian)

Freud, S. (2011). Pis'ma k neveste [Letters to the bride]. Moscow: Azbuka-klassika. (in Russian)

Freud, S. (2012). Fragment analiza odnogo sluchaya isterii [A fragment of the analysis of one case of hysteria]. In S. Freud, Sobranie sochinenii: t. 5. Fobicheskie rasstroistva. Malen'kii Gans. Dora [Collection of works: Vol. 5. Phobic disorders. Little Hans. Dora] (pp. 143-268). Saint Petersburg: Vostochno-Evropeiskii institut psikhoanaliza. (in Russian)

Freud, S. (2018). Sobranie sochinenii:t. 8. Psikhopatologiya obydennoi zhizni [Collection of works. Vol. 8. The psychopathology of everyday life]. Saint Petersburg: Vostochno-Evropeiskii institut psikhoanaliza. (in Russian)

Freud, S. (2019). O psikhogeneze odnogo sluchaya zhenskoi gomoseksual'nosti [On the psychogenesis of one case of female homosexuality]. In S. Freud, Sobranie sochinenii:t. 10-11. Dinamika perenosa. Psikhoanaliticheskaya klinicheskaya teoriya [Collection of works: Vol. 10-11. The dynamics of transference. The psychoanalytic clinical theory] (pp. 349-378). Saint Petersburg: VostochnoEvropeiskii institut psikhoanaliza. (in Russian)

Mokhovikov, A. N. (Ed.). (2013). Suitsidologiya: proshloe i nastoyashchee: Problema samoubiistv v trudakh filosofov, sotsiologov, psikhoterapevtov i v khudozhestvennykh tekstakh [Suicidology: past and present: The problem of suicide in works of philosophers, sociologists, psychotherapists and in literary texts]. Moscow: Kogito-Tsentr. (in Russian)

Polozhii, B. S. (2016). Suitsidy v Rossii $i$ v Evrope [Suicides in Russia and Europe]. Moscow: Meditsinskoe informatsionnoe agentstvo. (in Russian)

Popov, Yu. V., \& Pichikov, A. A. (2017). Suitsidal'noe povedenie u podrostkov [Suicidal behavior in adolescents]. Saint Petersburg: SpetsLit. (in Russian)

Reshetnikov, M. M. (2003). Psikhodinamika i psikhoterapiya depressii [Psychodinamics and psychotherapy of depression]. Saint Petersburg: Vostochno-Evropeiskii institut psikhoanaliza. (in Russian)

Reshetnikov, M. M. (2006). Intolerantnost' i terrorizm v Evrope [Non-tolerance and terrorism in Europe]. In Ideya nenasiliya $v$ XXI veke [The idea of non-violence in the XXI century] (pp. 226273). Perm: Perm State University. (in Russian) 
Reshetnikov, M. M. (2016). Istoriko-kul'turnye predposylki sozdaniya psikhoanaliza [Historical and cultural background of creation of psychoanalysis]. In M. M. Reshetnikov (Ed.), Psikhoanaliz [Psychoanalysis] (pp. 17-29). Moscow: Yurait. (in Russian)

Reshetnikov, M. M. (2017). Dva sluchaya zloupotrebleniya odnim patsientom [Two cases of misuse of one patient]. In M. M. Reshetnikov, Trudnosti i tipichnye oshibki nachala terapii [Difficulties and typical mistakes in the beginning of therapy] (2nd ed., pp. 225-240). Moscow: Yurait. (in Russian)

Reshetnikov, M. M. (2018). Psikhicheskaya travma [Psychic trauma] (2nd ed.). Moscow: Yurait. (in Russian)

Stekel, W. (2011). Ob isterii strakha [On the hysteria of fear]. In O. Rank (Ed.), Otchet o pervom chastnom Psikhoanaliticheskoi sobranii v Zal'tsburge 27 aprelya 1908 goda [A report on the First private Psychoanalytic meeting in Salzburg on April 27, 1908] (p. 23). Izhevsk: ERGO. (in Russian)

Mikhail M. Reshetnikov - Rector, East European Psychoanalytic Institute (University), Meritorious Scientist of Russia, DSc in Psychology, Professor.

Research Area: psychology, psychotherapy, social crisis, ecological and technogenic catastrophes, mass processes.

E-mail: veip@yandex.ru 